\title{
KOHESI GRAMATIKAL DAN MAKNA KONTEKSTUAL PADA LIRIK LAGU ALBUM BEGADANG CIPTAAN H. RHOMA IRAMA
}

\author{
Dita Hazwinda \\ MA Negeri 1 Pekanbaru, Indonesia \\ ditahazwinda25@gmail.com
}

\begin{abstract}
Music is not only about combination between tone and lyrics. If the combination is balance, the song will be qualified. Nowadays, music is not only about a right rhythm and melody, but the message as the song writer offers will be essential. The song writer must pay attention to the correlation between lyrics and contect which become a contectual meaning. The problem that raised in this research are 1) how the grammatical cohesion which contains in song Begadang from $\mathrm{H}$. Rhoma Irama, 2) what kind of contectual which contain in the lyrics of this song Begadang from $\mathrm{H}$. Rhoma Irama. This research is aimed to analyze element of grammatical cohesion and contectual meaning in lyric of Begadang song from $\mathrm{H}$. Rhoma Irama. Descriptive, and qualititative orientation were used in this research. All of the lyrics of Begadang song became the data of this research. This research is motivated by kertarikan authors see mothers in households using facebook. A housewife is a married woman and her family work menajalankan ranging from cooking, taking care to clean the house
\end{abstract}

Keywords: grammatical cohesion, contectual meaning, lyric of song

\begin{abstract}
ABSTRAK
Musik tidak hanya kombinasi antara nada dan lirik. Jika perpaduannya seimbang maka sebuah lagu akan menjadi berkualitas. Ternyata musik tidak hanya tentang ketepatan tempo, nada, dan iramanya saja. Pesan atau pokok permasalahan dalam sebuah lirik lagu yang ditulis oleh sang pencipta lagu juga sangat diperlukan. Tidak hanya itu, sang pencipta lagu juga harus memperhatikan hubungan antara isi lirik dan konteks yang akan membentuk sebuah makna kontekstual. Masalah dalam penelitian ini adalah 1) Bagaimanakah kohesi gramatikal yang terdapat pada lirik lagu album Begadang ciptaan H. Rhoma Irama, 2) Bagaimanakah makna kontekstual yang terdapat pada lirik lagu album Begadang ciptaan H. Rhoma Irama?Penelitian ini bertujuan untuk mendeskripsikan dan menganalisis unsur kohesi gramatikal dan makna kontekstual yang terdapat pada lirik lagu album Begadang ciptaan H. Rhoma Irama.Penulis menggunakan metode deskriptif, jenis penelitian pustaka, dan pendekatan kualitatif. Sumber data pada penelitian ini adalah seluruh lagu yang terdapat dalam album Begadang ciptaan H. Rhoma Irama yang berjumlah 10 (sepuluh) lagu.
\end{abstract}

Kata Kunci: kohesi gramatikal, makna kontekstual, lirik lagu PENDAHULUAN

Wacana sering dijumpai dalam kehidupan manusia, baik lisan maupun tulisan. Djajasudarma (2010:4) menjelaskan bahwa wacana berbentuk lisan disampaikan dengan cara lisan kepada pendengar. Penggunaan wacana secara lisan berarti penggunaan kalimat demi kalimat yang akan disampaikan oleh penutur kepada mitra tuturnya melalui bahasa yang bisa diterima. Wacana tulis harus saling berhubungan antara rentetan yang satu ke yang lain untuk mengetahui idea tau gagasan yang disampaikan dalam wacana tersebut.

Charlina dan Mangatur (dalam Kridalaksana, dalam Suladi dkk.,2000:16) menelaah syarat keutuhan wacana. Menurutnya, aspek yang memperlihatkan keutuhan wacana dapat dibedakan atas aspek semantis, aspek leksikal, aspek gramatikal, dan aspek fonologis. Dari aspek yang dipaparkan salah satunya aspek gramatikal yang menjadi perhatian penulis dalam melakukan penelitian ini memiliki arti penting bagi suatu wacana agar terbentuk pola kalimat yang baik dan 
benar, karena kohesi gramatikal merujuk pada perpautan bentuk yang diperlukan untuk menata pikiran dalam wujud dan kata serta kalimat yang tepat. Kohesi gramatikal terdiri atas referensi, substitusi, ellipsis, dan konjungsi.

Bagian yang mutlak dan harus ada dalam sebuah lirik yaitu adanya kohesi gramatikal. Lirik yang disusun dengan unsurunsur kohesi gramatikal akan mencerminkan isi dari curahan hati pribadi seseorang yang akan di dengar oleh pendengar atau penikmat lagu. Untuk dapat memahami pesan atau pokok permasalahan dalam sebuah lirik, pembaca harus memiliki kemampuan memahami dan menguasai kohesi gramatikal yang baik dan benar. Sehingga hal-hal yang diungkapkan oleh pencipta lagu dapat dengan mudah dimengerti oleh pendengar yang terdiri dari berbagai macam kalangan.

Peran kohesi gramatikal dimaksudkan untuk menciptakan kesinambungan antara satu larik dengan larik lainnya di dalam sebuah lirik agar pembaca maupun pendengar dapat menginterpretasikan lirik lagu tersebut dengan baik dan benar. Tarigan (2009:93) menegaskan bahwa "Untuk dapat memahami wacana dengan baik, diperlukan pengetahuan dan penguasaan kohesi yang baik pula, yang tidak saja bergantung pada pengetahuan kita tentang kaidah-kaidah bahasa, tetapi juga kepada pengetahuan kita mengetahui realitas, pengetahuan kita dalam proses penalaran, yang disebut penyimpulan sintaktik". Oleh karena itu kohesi gramatikal sangat diperlukan dalam penyempurnaan suatu lirik lagu.

Makna bermula dari kata, menurut Aminuddin (2003:52) "Selain bermula dari kata, makna juga memiliki hubungan erat dengan (1) sistem sosial budaya maupun realitas luar yang diacu, (2) pemakai, (3) konteks sosial-situasional dalam pemakaian." Makna tersebut tidak akan tervisualisasikan begitu saja, tanpa adanya komunikasi. Komunikasi yang terjadi adalah penyampaian perasaan curahan isi hati pencipta lagu atau penyanyi kepada pendengar yang sedang mendengarkan lagu tersebut. Dari pernyataan tersebut makna yang dimaksud ialah makna kontekstual. Pateda (2010:116) mengemukakan bahwa "Makna kontekstual atau makna situasional ini muncul sebagai akibat hubungan antara ujaran dan konteks". Berdasarkan pendapat Pateda tersebut, sangat mendukung kiranya dengan penelitian yang penulis ajukan salah satunya pada sumber data lirik lagu yang erat kaitannya dengan makna kontekstual.

Melalui kohesi gramatikal dan makna kontekstual itulah pencipta lagu mencurahkan isi hatinya dalam bentuk lirik dengan memperhatikan segi bentuk atau struktur kata di tiap lariknya serta menginterpretasikan isi lirik tersebut dengan makna kontekstual demi memperoleh efek tertentu. Hal ini sesuai dengan pendapat dari Semi (2012:106) menyatakan "Keandalan penulis memilih kata yang tepat dan menggugah merupakan segi lain yang harus dianalisis. Keberhasilan seorang penulis atau pengarang tidak hanya bergantung kepada kecemerlangan menemukan gagasan, tetapi lebih dari itu, ditentukan pula oleh kemampuan memilih kata." Dari kemampuan memilih kata tersebut maka terciptalah makna kontekstual sebagai akibat hubungan antara ujaran dan konteks. Kata yang ditelaah dalam penelitian ini adalah lirik lagu dalam sebuah teks yang ternyata tidak dapat dipisahkan dari unsur kohesi gramatikal dan makna kontekstual. Kemudian Halliday dan Hasan (1979:4-8) menambahkan bahwa kohesi sebagai suatu satuan semantis yang direalisasikan ke dalam tiga strata sistem bahasa, yaitu 1) makna (meaning) sebagai sistem semantis, 2) bentuk (wording) sebagai sistem leksikogramatikal, dan 3) bunyi dan tulisan (sounding/writing) sebagai sistem fonologis dan morfologis. Dari pengertian tersebut dapat ditafsirkan bahwa kohesi suatu wacana yang berupa pertalian unit semantis diwujudkan menjadi bentuk, gramatikal dan leksikal, dan selanjutnya diwujudkan menjadi suatu ekspresi dalam bentuk bunyi atau tulisan.

\section{METODOLOGI PENELITIAN}

Metode yang digunakan dalam penelitian ini adalah metode deskriptif. Sebagaimana yang dijelaskan oleh Sudaryanto (1993:62) bahwa "Metode deskriptif adalah metode penelitian yang dilakukan semata-mata berdasarkan fakta kebahasaan yang ada atau fenomena yang 
secara empiris hidup pada penuturnya". Metode deskriptif yang digunakan untuk memaparkan, menganalisis, dan mengklasifikasikan data unsur kohesi gramatikal dan makna kontekstual yang diperoleh, dan pendeskripsian ini berupa penggambaran bahasa sebagaimana adanya. Data yang diperoleh tersebut dideskripsikan, dianalisis secara terperinci dan sistematis diinterpretasikan untuk akhirnya disimpulkan.

\section{HASIL PENELITIAN}

Setelah dilakukan pengklasifikasian dan penelaahan terhadap 10 lirik lagu yang terdapat pada album Begadang ciptaan $\mathrm{H}$. Rhoma Irama, penulis menemukan beberapa jenis kohesi gramatikal yang digunakan oleh pencipta lirik lagu yaitu H. Rhoma Irama. Berikut ini disajikan analisis lirik lagu yang terdapat pada album Begadang ciptaan $\mathrm{H}$. Rhoma Irama.

Sederhananya, referensi adalah hubungan antara kata dan benda, tetapi lebih luas lagi referensi dikatakan sebagai hubungan bahasa dengan dunia. Faizah (2008:88) mengartikan, "Referensi adalah hubungan antara kata dengan objeknya." Kemudian Achmad dan Abdullah (2012:141) mengemukakan bahwa referensi adalah hubungan antara kata dengan benda (orang, tumbuhan, dan sesuatu lainnya) yang dirujuknya. Dari sudut analisis wacana, objek yang diacu oleh sebuah kata dapat di luar bahasa dan di dalam bahasa. Charlina dan Mangatur (2006:52) menggolongkan referensi menjadi dua bagian yaitu (a) referensi endofora dan (b) referensi eksofora.

Seperti kau menyakitiku (L.2-BT.1- BR.4) Sumber: Sengaja

Berdasarkan data (L.2-BT.1-BR.4) pada kata menyakitiku termasuk kohesi gramatikal unsur referensi. Disebut referensi karena salah satu jenis aspek gramatikal berupa satuan lingual yang mengacu pada satuan lingual lain. Satuan lingual $-k u$ mengacu pada bentuk orang yaitu sang pencipta lagu atau si penyanyi atau Elvi Sukaesih. Pengacuan dengan objek acuan ini terdapat di luar teks, karna pada lirik lagu tersebut tidak menuliskan atau menyebutkan acuan - $k u$ itu mengacu kepada siapa di dalam lirik lagu tersebut. Berdasarkan hal tersebut referensi $-k u$ ini mengarah ke referensi eksofora. Dengan demikian dapat dinyatakan bahwa pada lirik lagu album Begadang ciptaan H. Rhoma Irama terdapat kohesi gramatikal referensi eksofora pronomina persona pertama tunggal.

Kita bersama menari (L.10-BT.2-BR.2)

Sumber: Sya La La

Berdasarkan data (L.10-BT.2-BR.2) pada kata kita bersama termasuk kohesi gramatikal unsur referensi. Disebut referensi karena salah satu jenis aspek gramatikal berupa satuan lingual yang mengacu pada satuan lingual lain. Satuan lingual kita mengacu pada bentuk orang yaitu sang pencipta lagu atau si penyanyi atau H. Rhoma Irama dan Elvi Sukaesih. Pengacuan pada data ini mengacu pada satuan lingual lain yang terdapat di luar teks, karna pada lirik lagu tersebut tidak menuliskan atau menyebutkan acuan kita itu mengacu kepada siapa di dalam lirik lagu tersebut. Berdasarkan hal tersebut referensi kita ini mengarah ke referensi eksofora. Dengan demikian dapat dinyatakan bahwa pada lirik lagu album Begadang ciptaan H. Rhoma Irama terdapat kohesi gramatikal referensi eksofora pronomina persona pertama jamak.

Sengaja ku sakiti hatimu (L.2-BT.1BR.1)

Sumber: Sengaja

Berdasarkan data (L.2-BT.1-BR.1) pada kata hatimu termasuk kohesi gramatikal unsur referensi. Disebut referensi karena salah satu jenis aspek gramatikal berupa satuan lingual yang mengacu pada satuan lingual lain. Satuan lingual $-m u$ mengacu pada bentuk orang yaitu mantan kekasih dari si penyanyi atau Elvi Sukaesih. Pengacuan pada data ini mengacu pada satuan lingual lain yang terdapat di luar teks, karna pada lirik lagu tersebut tidak menuliskan atau menyebutkan acuan - $m u$ itu mengacu kepada siapa di dalam lirik lagu tersebut. Berdasarkan hal tersebut referensi $-m u$ ini mengarah ke referensi 
eksofora. Dengan demikian dapat dinyatakan bahwa pada lirik lagu album Begadang ciptaan H. Rhoma Irama terdapat kohesi gramatikal referensi eksofora pronomina persona kedua.

Katanya tiada mudah dilupakan (L.5BT.2-BR.4)

Sumber: Cinta Pertama

Berdasarkan data (L.5-BT.2-BR.4) pada kata katanya termasuk kohesi gramatikal unsur referensi. Disebut referensi karena salah satu jenis aspek gramatikal berupa satuan lingual yang mengacu pada satuan lingual lain. Satuan lingual -nya mengacu pada bentuk orang yaitu orang yang pernah atau sudah merasakan bagaimana rasanya jatuh cinta. Pengacuan pada data ini mengacu pada satuan lingual lain yang terdapat di luar teks, karna pada lirik lagu tersebut tidak menuliskan atau menyebutkan acuan -nya itu mengacu kepada siapa di dalam lirik lagu tersebut. Berdasarkan hal tersebut referensi -nya ini mengarah ke referensi eksofora. Dengan demikian dapat dinyatakan bahwa pada lirik lagu album Begadang ciptaan H. Rhoma Irama terdapat kohesi gramatikal referensi eksofora pronomina persona ketiga.

\section{Bahwa cinta itu sungguh mengasyikkan (L.5-BT.1-BR.4) \\ Sumber: Cinta Pertama}

Berdasarkan data (L.5-BT.1-BR.4) pada kata cinta itu termasuk kohesi gramatikal unsur referensi. Disebut referensi karena salah satu jenis aspek gramatikal berupa satuan lingual yang mengacu pada satuan lingual lain. Satuan lingual penunjuk umum kata itu, mengacu pada informasi yang sudah disampaikan. Pengacuan pada data ini mengacu pada satuan lingual lain yang terdapat di dalam teks yang disebut dengan referensi endofora. Pada data ini referensi endoforanya mengarah ke unsur anafora. Hal ini dapat dibuktikan dengan adanya perujukan silang pada unsur yang disebutkan terdahulu yaitu kali pertama si penyanyi mengalami dan merasakan indahnya jatuh cinta, seperti pada larik yang disebutkan sebelumnya Baru kali ini aku mengalami (L.5-BT.1-BR.1),
Bagaimana bila orang jatuh cinta (L.5-BT.1BR.2). Dengan demikian dapat dinyatakan bahwa pada lirik lagu album Begadang ciptaan H. Rhoma Irama terdapat kohesi gramatikal referensi endofora pronomina penunjuk umum kata itu.

Substitusi mempunyai referen setelah ditautkan dengan unsur yang diacunya. Secara umum penggantian itu dapat berupa kata ganti orang, tempat, dan sesuatu hal. Substitusi merupakan hubungan gramatikal yang lebih bersifat dengan hubungan kata dan makna. Substitusi dalam bahasa Indonesia bersifat nominal, verbal, klausa, atau campuran, seperti sama, seperti itu, sedemikian rupa, begitu, melakukan hal yang sama, dll.

$$
\begin{aligned}
& \text { Seperti kau menyakitiku (L.2-BT.1- } \\
& \text { BR.4) } \\
& \text { Sumber: Sengaja }
\end{aligned}
$$

Berdasarkan data (L.2-BT.1-BR.4) pada kata seperti termasuk kohesi gramatikal unsur substitusi. Disebut substitusi karena penyulihan atau proses hasil penggantian unsur bahasa oleh unsur lain yang acuannya tetap sama. Pada data seperti menunjukkan penggantian atas isi larik sebelumnya. Pada bagian lirik lagu tersebut menjelaskan tentang cara yang ingin dilakukan si penyanyi atau Elvi Sukaesih untuk membalas perlakuan yang telah dilakukan kekasihnya. Hal ini dibuktikan pada larik sebelumnya, yaitu Sengaja ku sakiti hatimu (L.2-BT.1-BR.1), Ku bercumbu di hadapanmu (L.2-BT.1-BR.2), dan Sengaja ku sakiti hatimu (L.2-BT.1-BR.3). Adanya substitusi data seperti menunjukkan penggantian bahwa si penyanyi atau Elvi Sukaesih ingin melakukan hal yang sama yang pernah dilakukan oleh kekasih hatinya dulu yang telah mengkhianatinya. Fungsi data seperti sebagai penggantian substitusi untuk menambah variasi bentuk, dinamisasi narasi, menghilangkan kemonotonan, dan memperoleh unsur pembeda. Data seperti bersifat substitusi campuran. Dengan demikian dapat dinyatakan bahwa pada lirik lagu album Begadang ciptaan $\mathrm{H}$. Rhoma Irama terdapat kohesi gramatikal substitusi yang bersifat campuran. 
Penggunaan konjungsi sebagai piranti

dalam bahasa Indonesia menunjukkan pola tertentu. Konjungsi digunakan dengan mempertimbangkan logika berpikir. Penggunaan konjungsi yang tidak mempertimbangkan logika akan membuat wacana menjadi tidak apik, terutama dilihat dari kepaduannya. Konjungsi sebagai alat relasi yang erat dapat dibagi atas beberapa bagian, terutama berdasarkan perilaku sintaksisnya, yakni: (1) konjungsi koordinatif, (2) konjungsi subordinatif, dan (3) konjungsi korelatif.

Sedangkan kau tahu bahwa dia itu sahabatku (L.2-BT.2-BR.3)

Sumber: Sengaja

Berdasarkan data (L.2-BT.2-BR.3) pada kata sedangkan termasuk kohesi gramatikal unsur konjungsi. Disebut konjungsi karena adanya partikel yang dipergunakan untuk menggabungkan kata dengan kata, frase dengan frase, klausa dengan klausa, kalimat dengan kalimat, atau paragraf dengan paragraf. Pada data sedangkan menunjukkan hubungan antara bagian-bagian dalam lirik lagu menjadi lebih eksplisit dan akan menjadi lebih kuat bila dibandingkan dengan hubungan yang tanpa menggunakan konjungsi. Pada data (L.2-BT.2BR.3) konjungsi sedangkan termasuk konjungsi koordinatif. Konjungsi koordinatif menghubungkan dua larik atau lebih pada larik sebelumnya sehingga terpadu dengan erat dan mempunyai kedudukan yang setara. Larik sebelumnya yang dimaksud adalah Ingatkah kala engkau berdua (L.2-BT.2-BR.1), Dengan gadis lain (L.2-BT.2-BR.2). Munculnya konjungsi koordinatif sedangkan pada larik setelahnya yang menyatakan apa yang dinyatakan dalam larik sebelumnya itu berlawanan. Dengan demikian dapat dinyatakan bahwa pada lirik lagu album Begadang ciptaan H. Rhoma Irama terdapat kohesi gramatikal konjungsi koordinatif makna perlawanan.

Elipsis atau pelesapan merupakan penghilangan satuan lingual tertentu. Charlina dan Mangatur (2006:68) menjelaskan, "Elipsis adalah peniadaan kata atau satuan lain yang wujud asalnya dapat diramalkan dalam konteks luar bahasa." Dengan adanya elipsis kalimat yang sama tidak terus diulang, sehingga wacana akan tampak menjadi lebih efektif, dan penghilangan itu menjadi alat penghubung kalimat dalam wacana.

Mari menyanyi

Nyanyi yang merdu (L.3-BT.2-BR.2)

Menyanyi yang merdu

Sumber: Sampai Pagi

Berdasarkan data (L.3-BT.2-BR.2) pada kata nyanyi merupakan kohesi gramatikal unsur elipsis atau pelesapan. Elipsis adalah pelesapan kata atau satuan lain yang wujud asalnya dapat diramalkan dalam konteks luar bahasa. Elipsis dapat juga dikatakan penggantian nol atau zero; sesuatu yang ada tetapi tidak diucapkan atau tidak dituliskan. Kata nyanyi dapat diacu dari salah satu unsur yang sudah disebutkan pada larik sebelumnya yaitu kata menyanyi. Pelesapan pada larik tersebut bukan tanpa tujuan. Dalam hal ini, pencipta lagu melakukan pelesapan dengan tujuan untuk menghasilkan larik lagu yang efektif, atau dengan kata lain demi efektivitas larik lagu maka pelesapan itu dilakukan. Dengan larik lagu yang efektif maka akan terjadi efisiensi dalam pemakaian bahasa pada lagu, artinya dengan kata-kata yang terbatas namun dapat mengungkapkan makna dan maksud yang diinginkan. Pada data (L.3-BT.2BR.2) unsur yang dilesapkan tersebut berupa verba. Dengan demikian dapat dinyatakan bahwa pada lirik lagu album Begadang ciptaan H. Rhoma Irama terdapat kohesi gramatikal elipsis.

Makna Kontekstual Tujuan
Kalau terlalu banyak begadang
Muka pucat karena darah berkurang
Kalau sering kena angin malam
Segala penyakit akan mudah datang
Darilah itu sayangi badan
Jangan begadang setiap malam (L.1-
BT.3-BR.6)
Sumber: Begadang
Konteks tujuan, misalnya tujuannya
meminta dan mengharapkan sesuatu,
orang akan mencari kata-kata yang

Kohesi Gramatikal dan Makna Kontekstual pada Lirik Lagu Album Begadang Ciptaan H. Rhoma Irama 
maknanya meminta. Pada data Jangan begadang setiap malam (L.1-BT.3-BR.6) termasuk makna kontekstual tujuan. Hal ini dapat dibuktikan pada kutipan larik yang sudah penulis deskripsikan, yang disampaikan oleh si penyanyi atau $\mathrm{H}$. Rhoma Irama bahwa kegiatan begadang bukanlah kegiatan yang harus dilakukan. Banyak dampak negatif yang datang jika kita selalu begadang setiap malam. Salah satunya dampak bagi tubuh. Tidak hanya kekurangan darah akibat kurangnya tidur melainkan juga mendatangkan berbagai macam penyakit yang tidak diinginkan. Pada data (L.1-BT.3-BR.6) mewakili makna kontekstual tujuan yang mewakili seluruh isi dari lirik lagu. Sehingga dapat penulis simpulkan bahwa tujuannya adalah mengingatkan dampak buruk dari begadang. Dengan demikian makna kontekstual pada lirik lagu album Begadang ciptaan H. Rhoma Irama Lirik lagu di atas yang berjudul Begadang terdapat konteks tujuan.

Makna Kontekstual Suasana Hati Pendengar

Kalau terlalu banyak begadang

Muka pucat karena darah berkurang

Kalau sering kena angin malam

Segala penyakit akan mudah datang

Darilah itu sayangi badan

Jangan begadang setiap malam (L.1BT.3-BR.6)

Sumber: Begadang

Konteks suasana hati pendengar turut mempengaruhi kata yang berakibat pula pada makna. Misalnya suasana hati yang jengkel akan memungkinkan kata-kata yang bermakna jengkel pula. Pada data Jangan begadang setiap malam (L.1-BT.3-BR.6) termasuk makna kontekstual suasana hati pendengar. Hal ini dapat dibuktikan pada kutipan larik yang sudah penulis deskripsikan, yang disampaikan oleh si penyanyi atau $\mathrm{H}$. Rhoma Irama bahwa jika terlalu sering begadang di tiap malam, maka banyak dampak buruk yang diakibatkannya. Terutama bagi kesehatan tubuh. Tidak hanya kekurangan darah namun juga dapat mendatangkan segala macam penyakit yang tidak diinginkan. Sebelum itu semua terjadi, lebih baik menyayangi dan menjaga kesehatan tubuh kita dengan tidak terlalu sering begadang. Pada data (L.1-BT.3-
BR.6) mewakili makna kontekstual suasana hati pendengar yang mewakili seluruh isi dari lirik lagu. Sehingga dapat penulis simpulkan bahwa suasana hati pendengar yaitu merasa diingatkan dan setuju apa yang disampaikan oleh H. Rhoma Irama bahwa kegiatan begadang dapat merusak kesehatan badan. Dengan demikian makna kontekstual pada lirik lagu album Begadang ciptaan $\mathrm{H}$. Rhoma Irama Lirik lagu di atas yang berjudul Begadang terdapat konteks suasana hati pendengar.

Makna Kontekstual Situasi

Begadang jangan begadang (L.1-
BT.1-BR.1)
Kalau tiada artinya
Begadang boleh saja....aaaa
Kalau ada perlunya
Sumber: Begadang
Konteks situasi memaksa pembicara mencari kata yang maknanya berkaitan dengan situasi. Misalnya situasi kedukaan akan memaksa orang untuk mencari kata yang maknanya berkaitan dengan situasi itu. Pada data Begadang jangan begadang (L.1-BT.1BR.1) termasuk makna kontekstual situasi. Hal ini dapat dibuktikan pada kutipan larik yang sudah penulis deskripsikan, yang disampaikan oleh si penyanyi atau $\mathrm{H}$. Rhoma Irama bahwa larangan untuk melakukan kegiatan begadang setiap malam dapat mendatangkan dampak buruk bagi kesehatan. Begadang diperbolehkan jika ada perlunya saja. Pada data (L.1-BT.1-BR.1) mewakili makna kontekstual situasi yang mewakili seluruh isi dari lirik lagu. Sehingga dapat penulis simpulkan bahwa situasinya yaitu melarang. Pada bagian larik tersebut menyatakan larangan untuk tidak begadang jika memang tidak ada keperluan. Dengan demikian makna kontekstual pada lirik lagu album Begadang ciptaan H. Rhoma Irama Lirik lagu di atas yang berjudul Begadang terdapat konteks situasi.
Makna Kontekstual Objek
Kalau terlalu banyak begadang (L.1- BT.3-BR.1)
Muka pucat karena darah berkurang
Kalau sering kena angin malam 
Segala penyakit akan mudah datang

Darilah itu sayangi badan

Jangan begadang setiap malam

Sumber: Begadang

Konteks objek yang mengacu kepada fokus pembicaraan akan mempengaruhi makna kata yang digunakan. Misalnya fokus pembicaraan adalah soal ekonomi. Pada data Kalau terlalu banyak begadang (L.1-BT.3BR.1) termasuk makna kontekstual objek. Hal ini dapat dibuktikan pada kutipan larik yang sudah penulis deskripsikan, yang disampaikan oleh si penyanyi atau H. Rhoma Irama bahwa hal yang dijelaskan berkenaan dengan larangan begadang dan akibat buruknya bagi kesehatan jika kegiatan begadang tersebut hampir tiap malam dilakukan. Pada data (L.1-BT.3-BR.1) mewakili makna kontekstual objek yang mewakili seluruh isi dari lirik lagu. Sehingga dapat penulis simpulkan bahwa objeknya yaitu begadang. Dengan demikian makna kontekstual pada lirik lagu album Begadang ciptaan H. Rhoma Irama Lirik lagu di atas yang berjudul Begadang terdapat konteks objek.

\section{SIMPULAN}

Berdasarkan penelitian dan hasil pembahasan yang penulis lakukan maka ditemukannya 146 data unsur kohesi gramatikal dan 40 data makna kontekstual. Kohesi gramatikal terdiri dari (1) referensi berjumlah 111 data terdiri atas 84 data referensi eksofora dan 27 data referensi endofora, (2) substitusi berjumlah 7 data, (3) konjungsi berjumlah 26 data terdiri atas 9 data konjungsi koordinatif, dan 16 data konjungsi subordinatif (4) ellipsis berjumlah 2 data. Sedangkan makna kontekstual terdiri dari (1) konteks tujuan berjumlah 10 data, (2) konteks suasana hati pendengar 10 data, (3) konteks situasi berjumlah 10 data, dan (4) konteks objek berjumlah 10 data. Dengan demikian dapat disimpulkan bahwa kohesi gramatikal dan makna kontekstual pada lirik lagu album Begadang ciptaan H. Rhoma Irama telah menggunakan unsur kohesi gramatikal dan makna kontekstual dengan benar.
REFERENSI

Alisjahbana, S Takdir. 1980. Tata Bahasa Baru Bahasa Indonesia. Jakarta Selatan: Dian Rakyat.

Alwi, Hasan dkk. 1998. Tata Bahasa Baku Bahasa Indonesia. Jakarta : Balai Pustaka.

Aminuddin. 2011. Semantik Pengantar Studi Tentang Makna. Bandung : Sinar Baru Algensindo.

Arikunto, Suharsimi. 2006. Prosedur Penelitian. Jakarta: Rineka Cipta.

Chaer, Abdul. 2007. Linguistik Umum. Jakarta: Rineka Cipta.

Darma, Yoce Aliah. 2013. Analisis Wacana Kritis. Bandung: Yrama Widya

Darma, Yoce Aliah. 2014. Analisis Wacana Kritis dalam Multiperspektif. Bandung: Refika Aditama.

Depdiknas. 2008. Kamus Besar Bahasa Indonesia. Edisi Keempat. Jakarta: Gramedia Pustaka Pertama.

Djajasudarma, T. Fatimah. 2010. Wacana: Pemahaman dan Hubungan Antarunsur. Bandung: Refika Aditama.

Halliday, M.A.K \& Hasan, Ruqaiya. 1992. Bahasa, Konteks, dan Teks: Aspekaspek bahasa dalam pandangan semiotic sosial. Yogyakarta: Gadjah Mada University Press.

Hariadi, Try. 2015. "Analisis Lirik Lagu Sungai Kapuas Karya Paul Putra Frederick Tinjauan Tekstual dan Kontekstual”. IKIP-PGRI Pontianak: Jurnal.

Keraf, Gorys. 1984. Komposisi. Jakarta: Nusa Indah.

Kridalaksana, Harimurti. 2008. Kamus Linguistik. Jakarta: Gramedia Pustaka Utama.

Kridalaksana, Harimurti. 1990. Kelas Kata dalam Bahasa Indonesia. Jakarta: Gramedia.

Lubis, Hamid Hasan. 1993. Analisis Wacana Pragmatik. Bandung: Angkasa.

Mahsun. 2006. Metode Penelitian Bahasa: Tahapan strategi, metode, dan tekniknya. Jakarta: RajaGrafindo Persada. 
Moeliono, Anton M (Ed). 2003. Tata Bahasa Baku Bahasa Indonesia. Jakarta: Balai Pustaka.

Parera, J. D. 2004. Teori Semantik. Jakarta: Erlangga.

Pateda, Mansoer. 2010. Semantik Leksikal. Jakarta: Rineka Cipta.

Semi, M. Atar. 2012. Metode Penelitian Sastra. Bandung: Angkasa.

Sudaryat, Yayat. 2008. Makna dalam Wacana: Prinsip-prinsip Semantik dan Pragmatik. Bandung: Yrama Widya.

Sugiyono. 2011. Metode Penelitian Kombinasi (Mixed Methods). Bandung: Alfabeta.

Sumarta, Karsinem. 2013. Cara Mudah Menulis Skripsi. Pekanbaru: Forum Kerakyatan.

Tarigan, Henry Guntur. 2009. Pengajaran Wacana. Bandung: Angkasa.

Wardany, Liza. 2015. "Makna Kontekstual Bahasa Iklan Susu Formula di Stasiun Televisi MNCTV". Universitas Islam Riau: Skripsi.

Hamalik,Oemar, 1983. Metode Belajar dan Kesulitan Belajar ,Bandung,Penerbit Tarsito.

Nazir,Mohammad.1985. Metode Penelitian Survai,Jakarta,Penerbit Lembaga Penelitian Pendidikan dan Penerangan

Rinderiyana, Aidin Adlan. 2011. Bimbingan Praktis Penelitian Tindakan Kelas.

Kudus: Dita Kurnia. 